\title{
ASAS IKTIKAD BAIK DALAM KONTRAK ELEKTRONIK
}

\author{
Ardiana Hidayah \\ Fakultas Hukum, Universitas Palembang \\ E-mail: dianahidayah083@gmail.com
}

\begin{abstract}
Electronic Contract as an agreement between the parties using an electronic system. Electronic System is a series of electronic devices and procedures that serve to prepare, collect, process, analyze, store, display, announce, transmit, and / or disseminate electronic information. All forms of agreements including electronic contracts must be carried out in good faith based on Article 1338 paragraph 3 of the Civil Code. The principle of good faith is the principle for the parties, namely the business actor and the consumer must carry out the substance of the contract based on strong trust or belief or the goodwill of the parties. The phases in the implementation of good faith include the phase before the contract occurs, the phase when the contract occurs or takes place until the phase after the contract is executed.

Keywords: Electronic Contracts; Principles of Good Faith
\end{abstract}

\begin{abstract}
Abstrak
Kontrak Elektronik sebagai suatu perjanjian para pihak dengan menggunakan sistem elektronik. Sistem Elektronik merupakan serangkaian perangkat dan prosedur elektronik yang berfungsi mempersiapkan, mengumpulkan, mengolah, menganalisis, menyimpan, menampilkan, mengumumkan, mengirimkan, dan/atau menyebarkan informasi elektronik. Segala macam bentuk perjanjian termasuk pada kontrak elektronik harus dilaksanakan dengan itikad baik (good faith) berdasarkan pada Pasal 1338 ayat 3 Kitab Undang-Undang Hukum Perdata. Asas iktikad baik merupakan asas bagi para pihak, yaitu pihak pelaku usaha dan pihak konsumen harus melaksanakan substansi kontrak berdasarkan kepercayaan atau keyakinan yang kokoh maupun kemauan baik dari para pihak. Adapun fase dalam penerapan iktikad baik meliputi fase sebelum terjadinya kontrak, fase saat terjadinya atau berlangsungnya kontrak sampai pada fase setelah kontrak dilakukan.
\end{abstract}

Kata Kunci: Kontrak Elektronik; Asas Iktikad Baik

\section{PENDAHULUAN}

Salah satu bentuk

perkembangan dari hukum perjanjian

yaitu munculnya kontrak elektronik $(e$ -

contract) yang diperkenalkan dalam

UNCITRAL Model Law on Electronic

Commerce pada tahun 1996. Kemudian

pada tahun 2008, dengan

diundangkannya Undang-Undang

Nomor 11 Tahun 2008 Tentang

Informasi dan Transaksi Elektronik

(UU-ITE) ketentuan tentang $e$-contract diakui dalam hukum positif. Akan tetapi, model law UNCITRAL dan UU-

ITE tidak menjelaskan secara eksplisit bentuk dari $e$-contract. Sehingga dapat dipahami bahwa e-contract menjadi berbeda dan bisa menimbulkan kekeliruan. ${ }^{1}$

\footnotetext{
1 Bambang Pratama, "Mengenal Kontrak Elektronik, Click-Wrap Agreement Dan Tanda Tangan Elektronik," 2017, https://businesslaw.binus.ac.id/2017/03/31/mengenal-kontrakelektronik-click-wrap-agreement-dan-tandatangan-elektronik/.
} 
Ardiana Hidayah, Asas Iktikad Baik dalam Kontrak Elektronik, Halaman 155-164

Edmon Makarim memberikan pengertian kontrak elektronik atau $e$ contract adalah suatu perikatan ataupun hubungan hukum yang dilakukan secara elektronik dengan memadukan jaringan (networking) dari sistem informasi berbasiskan computer (computer based information system) dengan sistem komunikasi yang berdasarkan atas jaringan dan jasa telekomunikasi (telecommunication based) yang selanjutnya difasilitasi oleh keberadaan computer global internet (network of network). ${ }^{2}$

E-contract merupakan kontrak dibuat secara elektronik dengan cara interaksi antara pihak yang ditawarkan dengan sistem elektronik. E-contract atau kontrak elektronik lebih sering ditemui dalam hubungan hukum antara produsen dengan konsumen. Kontrak elektronik telah diakui dalam Pasal 8 ayat (1) United Convention on the Use of Electronic Communications in International Contracts sebagai kontrak yang sah dan mengikat para pihaknya, sehingga kemudahan dan efisiensi kontrak elektronik sering

2 Dimas Prasojo, "Hal-Hal Penting Dalam Perjanjian Elektronik (Clik-Wrap Ageement)," 2019, https://www.daya.id/usaha/artikeldaya/hukum-perizinan/hal-hal-penting-dalamperjanjian-elektronik-clik-wrap-agreement-. digunakan oleh pelaku usaha dalam kegiatan perdagangan. ${ }^{3}$

Pada perkembangannya walaupun ketentuan telah ada tetapi belum menjamin sepenuhnya dapat melindungi konsumen yang bertransaksi secara elektronik khususnya transaksi menggunakan kontrak elektronik. Sedangkan konsumen, dalam kontrak elektronik memiliki posisi yang lebih lemah dari pelaku usaha, hal ini disebabkan oleh karakteristik kontrak elektronik itu sendiri dan lemahnya peraturan mengenai perlindungan konsumen di tingkat internasional dan nasional. Penekanan pada asas iktikad baik sangat diperlukan bagi para pihak, baik pelaku usaha maupun konsumen dalam melakukan kontrak elektronik.

\section{PEMBAHASAN}

Kontrak baik dalam bentuk tertulis maupun dalam bentuk elektronik harus bersandar pada ketentuan perjanjian dalam Kitab Undang-Undang Hukum Perdata. Sehingga kontrak elektronik juga harus memenuhi persyaratan sahnya perjanjian yang berdasarkan pada Pasal

\footnotetext{
${ }^{3}$ Prasojo.
} 
Ardiana Hidayah, Asas Iktikad Baik dalam Kontrak Elektronik, Halaman 155-164

1320 Kitab Undang-Undang Hukum

Perdata.

Untuk sahnya perjanjian diperlukan empat syarat, yaitu: ${ }^{4}$

1. Sepakat mereka mengikatkan dirinya;

2. Kecakapan untuk membuat suatu perikatan;

3. Suatu hal tertentu;

4. Suatu sebab yang halal.

Pasal 1320 menerangkan tentang syarat yang harus dipenuhi untuk lahirnya suatu perjanjian. Syarat tersebut baik mengenai pihak yang membuat perjanjian disebut dengan syarat subjektif maupun syarat yang berhubungan dengan isi perjanjian yakni syarat objektif.

Kesepakatan adalah persesuaian kehendak antara para pihak, yaitu bertemunya antara penawaran dan penerimaan. Kesepakatan ini dapat dicapai dengan berbagai cara, baik dengan tertulis maupun secara tidak tertulis. Dikatakan tidak tertulis, bukan lisan karena perjanjian dapat saja terjadi dengan cara tidak tertulis dan juga tidak lisan, tetapi bahkan hanya dengan menggunakan simbol-simbol

4 Ahmadi Miru and Sakka Pati, Hukum Perikatan (Penjelasan Makna Pasal 1233 Sampai 1456 BW) (Jakarta: Rajawali Pers, 2014). atau dengan cara lainnya yang tidak secara tertulis. ${ }^{5}$

Kecakapan merupakan kemampuan berdasarkan hukum dalam melakukan perbuatan hukum dalam hal ini melakukan perjanjian. Kecakapan berdasarkan hukum perdata ditandai dengan dicapainya usia 21 tahun atau telah menikah (walaupun usianya belum mencapai 21 tahun). Tetap dianggap cakap bila seseorang telah bercerai walaupun usianya belum mencapai 21 tahun. Seseorang telah berusia 21 tahun, akan tetapi dianggap tidak cakap disebabkan di bawah pengampuan, misalnya dikarenakan gila.

Syarat ketiga dan keempat dalam perjanjian termasuk dalam syarat objektif. Suatu perjanjian tidak dapat dilakukan tanpa objek yang tertentu. Sebab yang halal juga merupakan syarat tentang isi perjanjian. Kata halal bukan sebagai untuk memperlawankan kata haram dalam hukum Islam, tetapi yang dimaksudkan disini adalah isi perjanjian tersebut tidak dapat bertentangan dengan undang-undang kesusilaan dan ketertiban umum. ${ }^{6}$

\footnotetext{
${ }^{5}$ Miru and Pati.

${ }^{6}$ Miru and Pati.
} 
Ardiana Hidayah, Asas Iktikad Baik dalam Kontrak Elektronik, Halaman 155-164

Perjanjian dalam kontrak

elektonik dapat dikategorikan sebagai "perjanjian/kontrak innominat (tidak bernama)", sebab istilah kontrak elektronik tidak disebutkan dalam Kitab Undang-Undang Hukum Perdata atau Kitab Undang-Undang Hukum Dagang serta munculnya akibat adanya perkembangan dalam dunia bisnis. ${ }^{7}$

Berdasarkan pada peraturan perundang-undangan yang berlaku, perjanjian dalam bentuk kontrak elektornik diatur dalam UndangUndang Nomor 11 Tahun 2008 sebagaimana telah diubah menjadi Undang-Undang Nomor 19 Tahun 2016 tentang Informasi dan Transaksi Elektronik, dalam Pasal 1 angka 17 yaitu :"Kontrak Elektronik adalah perjanjian para pihak yang dibuat melalui Sistem Elektronik."

Sistem Elektronik berdasarkan dalam Pasal 1 angka 5 yang menyebutkan bahwa: "Sistem Elektronik adalah serangkaian perangkat dan prosedur elektronik yang berfungsi mempersiapkan, mengumpulkan, mengolah, menganalisis, menyimpan, menampilkan, mengumumkan,

7 R Indra, "Pengertian Dan Kedudukan Perjanjian/Kontrak Elektronik," 2019, https://doktorhukum.com/pengertian-dankedudukan-perjanjian-kontrak-elektronik/. mengirimkan, dan/atau menyebarkan Informasi Elektronik.” Sehingga kontrak elektronik telah mempunyai pengertian yang pasti serta memiliki landasan hukum kuat apabila dilakukan.

Pasal 18 UU ITE mengatur tentang tata cara penggunaan kontrak elektronik, yakni sebagai berikut:

1. Transaksi Elektronik yang dituangkan ke dalam Kontrak Elektronik mengikat para pihak;

2. Para pihak memiliki kewenangan untuk memilih hukum yang berlaku bagi Transaksi Elektronik internasional yang dibuatnya;

3. Jika para pihak tidak melakukan pilihan hukum dalam Transaksi Elektronik internasional, hukum yang berlaku didasarkan pada asas Hukum Perdata Internasional;

4. Para pihak memiliki kewenangan untuk menetapkan forum pengadilan, arbitrase, atau lembaga penyelesaian sengketa alternatif lainnya yang berwenang menangani sengketa yang mungkin timbul dari Transaksi Elektronik internasional yang dibuatnya; 
Ardiana Hidayah, Asas Iktikad Baik dalam Kontrak Elektronik, Halaman 155-164

5. Jika para pihak tidak melakukan pilihan forum sebagaimana dimaksud pada ayat (4), penetapan kewenangan pengadilan, arbitrase, atau lembaga penyelesaian sengketa alternatif lainnya yang berwenang menangani sengketa yang mungkin timbul dari transaksi tersebut, didasarkan pada asas Hukum Perdata Internasional.

Semua perjanjian termasuk dalam kontrak elektronik harus dilaksanakan dengan itikad baik (te goeder trouw; in good faith,) yang berdasarkan pada Pasal 1338 ayat 3 Kitab Undang-Undang Hukum Perdata. Asas ini menegaskan bahwa para pihak dalam membuat perjanjian harus didasarkan pada itikad baik dan kepatutan, hal tersebut memberikan pengertian bahwa pembuatan perjanjian antara para pihak harus didasarkan pada kejujuran untuk mencapai tujuan bersama. Pelaksanaan perjanjian juga harus mengacu pada apa yang patut dan seharusnya diikuti dalam pergaulan masyarakat. ${ }^{8}$

\footnotetext{
${ }^{8}$ Ery Agus Priyono, "Peranan Asas Itikad Baik Dalam Kontrak Baku(Upaya Menjaga Keseimbangan Bagi Para Pihak)," Diponegoro Private Law Review 1, no. 1 (2017): 13-22.
}

Pengaturan dalam Pasal 1338

ayat 3 yang menetapkan persetujuan harus dilaksanakan dengan iktikad baik (contractus bonafidei-kontrak berdasarkan iktikad baik). Hal tersebut bermaksud bahwa perjanjian dilaksanakan menurut kepatutan dan keadilan. P.L.Werry dalam istilah redelijkheid en billijkheid yang berarti budi dan kepatutan, beberapa terjemahan lain menggunakan kewajaran dan keadilan, atau kepatutan dan keadilan, Sehingga redelijkheid memiliki arti rasional, dapat diterima oleh nalar dan akal sehat, sedangkan billijkheid berarti patut dan adil. Dengan demikian itu mengandung makna semua yang dapat dirasakan dan dapat diterima nalar dengan baik, wajar dan adil, yang diukur dengan normanorma objektif yang bersifat tidak tertulis dan bukan berasal dari subjektif dari para pihak. ${ }^{9}$

Asas iktikad baik merupakan asas bahwa para pihak, yaitu pihak pelaku usaha dan pihak konsumen harus melaksanakan substansi kontrak berdasarkan kepercayaan atau keyakinan yang kokoh maupun kemauan baik dari para pihak. Asas

9 Agus Yudha Hernoko, Hukum Perjanjian Asas Proporsionalitas Dalam Kontrak Komersil (Jakarta: Kencana Prenada Media Group, 2010). 
Ardiana Hidayah, Asas Iktikad Baik dalam Kontrak Elektronik, Halaman 155-164

itikad baik ini terbagi menjadi dua macam, yakni itikad baik relatif dan itikad baik mutlak. Itikad baik relatif yaitu seseorang memperhatikan sikap dan tingkah laku yang nyata dari subjek. Pada itikad baik mutlak penilaian terletak pada akal sehat dan keadilan serta dibuat ukuran yang obyektif untuk menilai keadaan menurut norma-norma yang obyektif. ${ }^{10}$

Daya berlaku iktikad baik (goede trouw; good faith) berdasarkan pendapat J.M van Dunne meliputi seluruh proses kontrak yang diistilahkan dengan the rise and fall of contract. Sehingga iktikad baik meliputi tiga fase perjalanan kontrak, yaitu: pre contractuele fase, contractuele fase, dan postcontractuele fase. ${ }^{11}$ Fase dalam penerapan iktikad baik meliputi fase sebelum terjadinya kontrak, fase saat terjadinya atau berlangsungnya kontrak sampai pada fase setelah kontrak dilakukan.

Asas iktikad baik itu mempunyai dua pengertian yaitu : ${ }^{12}$

10 “Asas Itikad Baik Sebagai Landasan Pembuatan Perjanjian," 2015, https://www.gresnews.com/berita/tips/98052asas-itikad-baik-sebagai-landasan-pembuatanperjanjian/.

11 Hernoko, Hukum Perjanjian, Asas Proporsionalitas Dalam Kontrak Komersil.

${ }^{12}$ Miftah Arifin, "Membangun Konsep Ideal Penerapan Asas Iktikad Baik Dalam Hukum Perjanjian," Jurnal Ius Constituendum 5, no. 1
1. Iktikad baik dalam arti obyektif, bahwa suatu perjanjian yang dibuat haruslah dilaksanakan dengan mengindahkan normanorma kepatutan dan kesusilaan yang berarti bahwa perjanjian itu harus dilaksanakan sedemikian rupa sehingga tidak merugikan salah satu pihak.

2. Iktikad baik dalam arti subyektif, yaitu pengertian iktikad baik yang terletak dalam sikap batin seseorang. Didalam hukum benda, iktikad baik ini bisa diartikan dengan kejujuran. Iktikad baik dalam arti subyektif bisa diartikan kejujuran seseorang dalam melakukan suatu perbuatan hukum yaitu apa yang terletak pada sikap batin seseorang pada waktu diadakan perbuatan hukum. Iktikad baik dalam arti subyektif ini diatur dalam Pasal 531 Buku II KUHPerdata.

Menurut Wirjono Prodjodikoro, iktikad baik dapat dibagi menjadi dua macam, yaitu: ${ }^{13}$

1. Iktikad baik pada waktu mulai berlakunya suatu hubungan hukum. Iktikad baik berupa perkiraan atau anggapan seseorang bahwa syarat-syarat yang diperlukan bagi dimulai hubungan hukum telah terpenuhi. Hal ini dalam

(2020): 68 https://journals.usm.ac.id/index.php/jic/article/ view/2119.

13 Hernoko, Hukum Perjanjian, Asas Proporsionalitas Dalam Kontrak Komersil. 
Ardiana Hidayah, Asas Iktikad Baik dalam Kontrak Elektronik, Halaman 155-164

konteks hukum memberikan perlindungan kepada pihak yang beriktikad baik, sedang bagi pihak yang beriktikad tidak baik (te kwader trouw) harus bertanggung jawab dan menanggung risiko. Iktikad baik bersifat subjektif dan statis.

2. Iktikad baik pada waktu pelaksanaan hak-hak dan kewajiban-kewajiban yang termaktub dalam hubungan hukum. Hal ini bersifat objektif dan dinamis mengikuti situasi sekitar perbuatan hukumnya. Titik berat iktikad baik disini terletak pada Tindakan yang akan dilakukan oleh kedua belah pihak, yaitu Tindakan sebagai pelaksanaan sesuatu hal.

Iktikad baik memiliki tiga fungsi utama, yaitu: ${ }^{14}$

1. Fungsi yang mengajarkan bahwa kontrak harus ditafsirkan menurut iktikad baik, yakni kontrak ditafsirkan dengan patut dan wajar (fair).

2. Fungsi menambah atau melengkapi (aanvullende werking van de goede trouw), artinya iktikad baik dapat menambah isi atau kata-kata perjanjian apabila terdapat hak dan kewajiban yang timbul diantara para pihak tidak secara tegas dinyatakan dengan kontrak.

3. Fungsi membatasi atau meniadakan (beperkende en

\footnotetext{
${ }^{14}$ Hernoko.
}

derogerende werking van de goede trouw), maksudnya adalah fungsi ini hanya dapat diterapkan apabila terdapat alasan-alasan yang amat penting (allen in spreekende gevallen).

Penafsiran pada iktikad baik berdasarkan kegiatan Simposium Hukum Perdata Nasional yang diselenggarakan Badan Pembinaan Hukum Nasional, maka dapat diartikan sebagai berikut: ${ }^{15}$

1. Kejujuran pada waktu membuat kontrak;

2. Pada tahap pembuatan ditekankan, apabila kontrak dibuat dihadapan pejabat, para pihak dianggap beriktikad baik;

3. Sebagai tahap kepatutan dalam tahap pelaksanaan, yaitu terkait suatu penilaian baik terhadap perilaku para pihak dalam melaksanakan apa yang telah disepakati dalam kontrak, semata-mata bertujuan untuk mencegah perilaku yang tidak patut dalam pelaksanaan kontrak tersebut.

Kontrak elektronik (e-contract) dapat diartikan sebagai perikatan atau hubungan hukum yang dilakukan secara elektronik dengan memadukan jaringan dari sistem informasi berbasiskan komputer dengan sistem

\footnotetext{
${ }^{15}$ Hernoko.
} 
Ardiana Hidayah, Asas Iktikad Baik dalam Kontrak Elektronik, Halaman 155-164

elektronik yang dilakukan dua orang atau lebih dengan menggunakan komputer atau jaringan berbasis internet. $^{16}$

Terdapat beberapa kontrak elektronik yang umum digunakan dalam perjanjian bisnis adalah sebagai berikut : ${ }^{17}$

a) Kontrak elektronik mail adalah suatu kontrak yang dibentuk secara sah melalui komunikasi email. Penawaran dan penerimaan dapat dipertukarkan melalui email atau kombinasi dengan komunikasi elektronika lainnya, dokumen tertulis atau faks.

b) Suatu kontrak dapat juga dibentuk melalui website dan jasa online lainnya, yaitu suatu website menawarkan penjualan barang dan jasa, kemudian konsumen dapat menerima penawaran dengan mengisi suatu formular yang terpajang pada layar monitor dan mentransmisikannya

c) Kontrak yang mencakup direct online transfer dari informasi dan jasa. Website digunakan sebagai medium of communication dan sekaligus sebagai medium of exchange.

d) Kontrak yang berisi Electronik Data Interchange (EDI), suatu pertukaran bisnis melalui secara elektronik melalui komputer milik para mitra dagang (trading Partners).

16 David Herianto Sinaga and I Wayan Wiryawan, "Keabsahan Kontrak Elektronik (EContract) Dalam Perjanjian Bisnis" 8, no. 9 (2020): 1385-95.

${ }^{17}$ Sinaga and Wiryawan. e) Kontrak "melalui internet yang disertai dengan lisensi click wrap dan shrink wrap software yang di download melalui internet lazimnya dijual dengan suatu lisensi click wrap. Lisensi tersebut muncul pada monitor pembeli pada saat pertama kali software akan dipasang dan calon pembeli ditanya tentang kesediaannya menerima persyaratan lisensi tersebut. Pengguna diberikan alternatif " $i$ accept" atau " $i$ don't accept". Sedangkan shrink wrap lazimnya merupakan lisensi yang dikirim dalam suatu bungkusan misalnya disket atau compact disc.

Kontrak elektronik sangat diperlukannya asas iktikad baik dalam menjalin hubungan kerjasama yang baik bagi para pihak yang melakukan kontrak. Dalam Pasal 17 UndangUndang Nomor 19 Tahun 2016 tentang Perubahan Atas Undang-Undang Nomor 11 Tahun 2008 tentang Informasi dan Transaksi Elektronik, dinyatakan bahwa penyelenggaraan Transaksi Elektronik dapat dilakukan dalam lingkup publik ataupun privat. Para pihak yang melakukan Transaksi Elektronik wajib beriktikad baik dalam melakukan interaksi dan/atau pertukaran Informasi Elektronik dan/atau Dokumen Elektronik selama transaksi berlangsung. Transaksi 
Ardiana Hidayah, Asas Iktikad Baik dalam Kontrak Elektronik, Halaman 155-164

Elektronik dituangkan dalam Kontrak

Elektronik yang mengikat para pihak.

\section{KESIMPULAN}

Kontrak Elektronik merupakan perjanjianyang dilakukan oleh para pihak dengan menggunakan sistem elektronik. Semua macam perjanjian termasuk dalam kontrak elektronik harus dilaksanakan dengan itikad baik (good faith) berdasarkan pada Pasal 1338 ayat 3 Kitab Undang-Undang Hukum Perdata. Asas iktikad baik merupakan asas bagi para pihak, yaitu pihak pelaku usaha dan pihak konsumen harus melaksanakan substansi kontrak berdasarkan kepercayaan atau keyakinan yang kokoh maupun kemauan baik dari para pihak. Adapun fase dalam penerapan iktikad baik meliputi fase sebelum terjadinya kontrak, fase saat terjadinya atau berlangsungnya kontrak sampai pada fase setelah kontrak dilakukan. Dalam kontrak elektronik sangat diperlukannya asas iktikad baik dalam menjalin hubungan kerjasama yang baikdan langgeng bagi para pihak yang melakukan kontrak.

\section{DAFTAR PUSTAKA}

Arifin, Miftah. "Membangun Konsep Ideal Penerapan Asas Iktikad Baik Dalam Hukum Perjanjian.” Jurnal Ius Constituendum 5, no. 1 (2020): 68.

https://journals.usm.ac.id/index.ph p/jic/article/view/2119.

"Asas Itikad Baik Sebagai Landasan Pembuatan Perjanjian," 2015. https://www.gresnews.com/berita/ tips/98052-asas-itikad-baiksebagai-landasan-pembuatanperjanjian/.

Hernoko, Agus Yudha. Hukum Perjanjian, Asas Proporsionalitas Dalam Kontrak Komersil. Jakarta: Kencana Prenada Media Group, 2010.

Indra, R. "Pengertian Dan Kedudukan Perjanjian/Kontrak Elektronik," 2019.

https://doktorhukum.com/pengerti an-dan-kedudukan-perjanjiankontrak-elektronik/.

Miru, Ahmadi, and Sakka Pati. Hukum Perikatan (Penjelasan Makna Pasal 1233 Sampai 1456 BW). Jakarta: Rajawali Pers, 2014.

Prasojo, Dimas. "Hal-Hal Penting Dalam Perjanjian Elektronik (Clik-Wrap Ageement)," 2019. https://www.daya.id/usaha/artikeldaya/hukum-perizinan/hal-halpenting-dalam-perjanjianelektronik-clik-wrap-agreement-.

Pratama, Bambang. "Mengenal Kontrak Elektronik, Click-Wrap Agreement Dan Tanda Tangan Elektronik," 2017. https://business- 
Ardiana Hidayah, Asas Iktikad Baik dalam Kontrak Elektronik, Halaman 155-164

law.binus.ac.id/2017/03/31/menge nal-kontrak-elektronik-clickwrap-agreement-dan-tandatangan-elektronik/.

Priyono, Ery Agus. "Peranan Asas Itikad Baik Dalam Kontrak Baku(Upaya Menjaga Keseimbangan Bagi Para Pihak)." Diponegoro Private Law Review 1, no. 1 (2017): 13-22.

Sinaga, David Herianto, and I Wayan Wiryawan. "Keabsahan Kontrak Elektronik (E-Contract) Dalam Perjanjian Bisnis" 8, no. 9 (2020): 1385-95. 